\title{
Comparative role of Squatting Posture \& Sitting Posture of Defecation in Anorectal Bleeding
}

\author{
Research Article
}

\author{
Anant V Shekokar ${ }^{*}$, Kanchan Borkar ${ }^{2}$ \\ 1. Professor \& HOD, 2. Associate Professor, \\ Department of Shalya Tantra, S.V.N.H.T Ayurved College, Rahuri Factory, \\ Rahuri, Maharashtra
}

\begin{abstract}
This paper compared role of squatting posture (Indian system of defecation) with sitting posture (Western system of defecation) in anorectal disorder specially rectum bleeding along with Awagaha Swedana. Total 60 patients were selected for the same and divided into two groups (30 in each group). Group-A \& Group-B patients were instructed to use squatting posture and sitting posture of defecation respectively along with treatment. All patients were suggested to follow Pathya-Apathya in terms of Dincharya. The relief in bleeding on $15^{\text {th }}$ day was observed 51\% \& 69\% in Group-A \& Group-B respectively. Reduction in burning sensation and uneasy defecation was observed more in Group-B as compared to Group-A. Study showed remarkable healing (73\%) in Group-B as compared to Group-A (57\%). Study suggested that western system of defecation causes less harm in rectum bleeding as compared to Indian system of defecation.
\end{abstract}

Keywords: Rectum Bleeding, Awagaha Swedana, , Ayurveda, Defecation Posture.

\section{Introduction:}

Ayurveda the science of traditional knowledge suggests various etiological factors for the Gudroga (anorectal diseases) and Sarveroga Malayatanani is one of them. The most of the Gudroga arises due to the accumulation of toxins in the body and disturbances of Malavisarjana Vidhi and other Dincharya. The medical science considers constipation as causative factor for the Gudroga such as rectal bleeding while defecation. Ayurveda described various factors for anorectal diseases like; Dincharya, Ritucharya, Dasaharavidha, Visheshayatana, Aaharopyogivarg, Sadavrita and Neendra. Ayurveda also described that proper functioning of Agni along with complete body detoxification process help in the management of Gudroga. Consumption of processed foods, red meat, baked goods, oily and spicy foods may causes bleeding on defecation. Hemorrhoid, fissure in ano, rectal polyp and sentinel tag are the responsible factors for anorectal bleeding. The seating position of defecation play significant role towards the disease prognosis and literature review suggests that the sitting positioning of defecation may offer more comfort in bleeding as compared to squatting posture. Looking towards the importance of this concept present investigation

*Corresponding Author:

\section{Anantkumar V Shekokar}

Professor \& HOD, Dept. of Shalya Tantra

S.V.N.H.T Ayurved College, Rahuri Factory,

Rahuri, Maharashtra.

Pin -413706

E-mail: dranantkumarshekokar@gmail.com compared efficacy of Awagaha Swedana in anorectal bleeding along with different posture of defecation i.e; sitting positioning and squatting posture (1-5).

\section{Figure 1. Different Types of Anorectal Diseases}

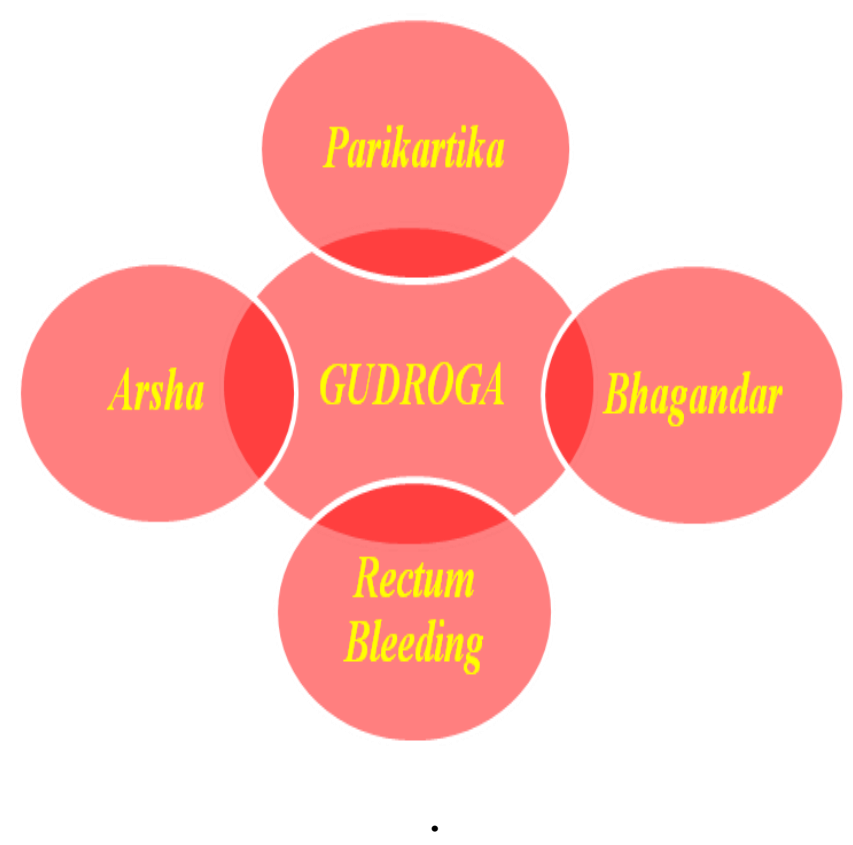

Aim: To compare the role of squatting posture with sitting posture for toileting (defecation) in anorectal bleeding.

Methods: Patients were divided into two groups (30 in each group). Group-A, patients were advised to use Indian System for defecation; while patients of Group-B 
were advised to use Western system for defecation.

Selection of patients

The patients of anorectal bleeding were registered irrespective of their sex, occupation and religion. Patients were explained the procedural protocol of treatment and then consent forms were obtained from all the patients.

\section{Inclusion criteria}

- Male female both.

- Age grouped between 20-50 years.

- Patients possessed symptoms of anorectal bleeding.

- Patients those were seeking long term therapy.

\section{Exclusion criteria}

- Age groups below 20 year and more than 50 year.

- Symptoms of anorectal bleeding not very clear.

- Patients possess anorectal disease in which bleeding is not very prompt.

- Patients possessed carcinoma of ano-rectum

- Patients under treatment of aspirin, and steroids drugs.

- Patients suffered with other diseases like; HIV infections, hepatitis-B, diabetes mellitus, hypertension, hemophilia, thrombocytopenia, \& other infections.

\section{Investigations}

$\mathrm{Hb} \%$, total leucocyte count, bleeding time, clotting time, blood sugar, HIV, hepatitis-B and stool examination, etc. were carried out before the treatment as per requirement.

\section{Materials \& Methodology:}

The present investigation was performed at Dept. of Shalya, S. V. N. H. T. Ayurved College and Hospital Rahuri Factory, Rahuri, Maharastra. In Group-A 30 patients and in Group-B 30 patients of diagnosed cases of anorectal bleeding were registered and advised to sitz bath.

\section{Awagaha Swedana (sitz bath)}

This involves immersion of body to achieve calming and cooling effects. This included Drava sweda, in which patient allowed to sit in tub containing dravya to offer beneficial effects. The optimum temperature of tub maintained within range of $38^{\circ} \mathrm{C}$ $42^{\circ} \mathrm{C}$. This procedure performed using recommended formulation. The lower part of patient submerged above the level of umbilicus. This overall boosts physiological functioning of body.

\section{Common procedures in both Groups}

Appropriate treatment was given initially and then Avagaha Swedan (water sitz bath) was advised twice in a day. Patients were also subjected to local application of Yashtimadhu Ghritta in the anus region by cotton swab at the site of bleeding twice a day for 15 days after sit'z bath daily two times. Patients were instructed to take water sitz bath for 15 minutes, after that Yashtimadhu Ghritta was given for local application in anal region.

\section{Advise to use specific toileting}

Patients of Group-A were advised to use Indian system for defecation (squatting posture) while patients of Group-B were instructed to use western system (sitting posture) of defecation along with other advised medical management i. e; Avagaha Swedan (sitz bath).

\section{Duration of treatment}

Patients were assessed on a weekly interval up to one month.

\section{Follow Up}

Follow up was taken after 15 days interval up to one month.

\section{Assessment Criteria:}

Following assessment criteria were adopted as mentioned in Table 1:

Table 1. Assessment criteria and ranking of descriptive symptoms.

\begin{tabular}{|c|l|c|}
\hline $\begin{array}{c}\text { S. } \\
\text { No. }\end{array}$ & \multicolumn{1}{|c|}{ Description } & Score \\
\hline \multicolumn{3}{|c|}{ Bleeding Assessment } \\
\hline 1 & Present & 1 \\
\hline 2 & Absent & 0 \\
\hline \multicolumn{3}{|c|}{ Bain Assessment } \\
\hline 1 & $\begin{array}{l}\text { Unbearable \& prolong pain most of } \\
\text { the time }\end{array}$ & 3 \\
\hline 2 & $\begin{array}{l}\text { Unbearable pain at the time of } \\
\text { defecation }\end{array}$ & 2 \\
\hline 3 & $\begin{array}{l}\text { Bearable pain at the time of } \\
\text { defecation }\end{array}$ & 1 \\
\hline 4 & No pain at the time of defecation & 0 \\
\hline & \multicolumn{1}{|c|}{ Burning sensation } \\
\hline 1 & $\begin{array}{l}\text { Reduction in defecation frequency } \\
\text { due to the fear of burning sensation }\end{array}$ & 1 \\
\hline 2 & $\begin{array}{l}\text { No reduction in defecation } \\
\text { frequency due to the fear of } \\
\text { burning sensation }\end{array}$ & 0 \\
\hline 1 & $\begin{array}{l}\text { Prevalence of most of the bleeding } \\
\text { symptoms }\end{array}$ & 2 \\
\hline 2 & Reduction in bleeding symptoms & 1 \\
\hline 3 & $\begin{array}{l}\text { Complete healing; no significant } \\
\text { bleeding symptoms }\end{array}$ & 0 \\
\hline
\end{tabular}

\section{Statistical test}

For the assessment of the results of study statistical analysis (t-test) was performed.

\section{Observations}

Most of the patients were belongs form age groups of more than 35 years and the number of male patients were more as compared to female patients since these disorders are common in male population and even they does not hesitate to disclose diseased condition. The patients possess common symptoms like; bowel disturbances, constipation and obstructed 
defecation syndrome. The patients also complaint about problem associated with Kshudha, Krura Koshtha, Pipasa and Agni (lack of digestive fire). Vattapittaja Prakriti was also reported in most of the patients. The prevalence of anorectal bleeding was found to be more common in patients belongs from poor socio-economic status due to the unbalance and unhygienic nutritional supply. Study observed that most of the patient possessed disturbed life style and do not follow rule of Swasthavritta which overall affects digestive system and leads anorectal disorders.

\section{Results \& Discussion}

The relief in bleeding on $15^{\text {th }}$ day was found to be $51 \%$ \& $69 \%$ in Group-A \& Group-B respectively. Reduction in burning sensation and uneasy defecation was observed more in Group-B as compared to GroupA. Study showed significant healing (reduction in bleeding symptoms) $73 \%$ in Group-B as compared to Group-A (57\%). Study suggested that western system of toileting means sitting posture of defecation causes less harm in rectum bleeding as compared to Indian system of toileting (straight posture for defecation) due to less strain and pressure over intra abdomen. The relief in symptoms were found to be statistically significant $(\mathrm{P}<0.001)$ after treatment in both groups but patients of Group-B acquired more beneficial effects as compared to Group-A as shown in Table 2. Study observed different symptoms of disease like; pain, burning sensation, bleeding and discomfort defecation and these symptoms arises may be due the various factors such as; constipation, irregular dietary habits and disturbed bowel physiology. Prevalence of pain were observed more while defecation and after defecation especially in anal region. The present study suggests that use of sitting posture for defecation support medical treatment of anorectal bleeding while use of squatting posture does not offers significant relief symptomatically. Study believes that seating posture of defecation affect disease prognosis since pressure on anal region play significant role in easy defecation. Squatting position affect contractibility and bowel movement; which provoke anorectal bleeding while sitting positioning offer narrow opening of anal sphincter and puborectalis muscle chokes rectum to maintain continence and also resist excess bleeding. The squatting posture somewhere possesses more pressure in anorectal region as compared to sitting posture which resulted anorectal bleeding. The Indian system for defecation does not offer comfort seating positioning and create extra burden over lower limb and thus intensify symptoms of anorectal bleeding (6-12).

The patients of Group-B those were used western system of toileting (straight posture) observed less complications of anorectal bleeding after treatment may be due to the straight positioning of bowel movement during defecation and complete hygienic cleaning through the force of water and less exertion of vein pressure.

Study also believed that use of western toilet offers relieve in bleeding since this posture does not possess excess pressure over anal portion, however western system of toileting may cause disadvantage like; constipation. Some patients reported that western toilet not offer significant relief in symptoms like; pain and burning sensation. Overall study suggested that straight posture of toileting reduces anorectal bleeding but patient those have problem of constipation should avoid use of western toilet.

Table 2. Results of study.

\begin{tabular}{|c|c|c|c|c|c|c|}
\hline S. No. & Signs and symptoms & $\mathbf{X}$ & SD & SE & $\mathbf{P}$ & Inference \\
\hline 1 & Bleeding Assessment & 0.621 & 0.523 & 0.081 & $<0.001$ & Significant \\
\hline 2 & Pain Assessment & 0.711 & 0.531 & 0.071 & $<0.001$ & Significant \\
\hline 3 & Burning sensation & 0.523 & 0.578 & 0.069 & $<0.001$ & Significant \\
\hline 4 & Healing Assessment & 0.654 & 0.521 & 0.073 & $<0.001$ & Significant \\
\hline \multicolumn{7}{|c|}{$\%$ of Relief in Symptoms } \\
\hline S. No. & Symptoms & \multicolumn{3}{|c|}{ Group $-A$} & \multicolumn{2}{|c|}{ Group-B } \\
\hline 1 & Bleeding Assessment & \multicolumn{3}{|c|}{51} & \multicolumn{2}{|c|}{69} \\
\hline 2 & Pain Assessment & \multicolumn{3}{|c|}{58} & \multicolumn{2}{|c|}{78} \\
\hline 3 & Burning sensation & \multicolumn{3}{|c|}{63} & \multicolumn{2}{|c|}{79} \\
\hline 4 & Healing Assessment & \multicolumn{3}{|c|}{57} & \multicolumn{2}{|c|}{73} \\
\hline
\end{tabular}

\section{Conclusion:}

The present investigation compared the role of squatting posture with sitting posture of defecation in anorectal bleeding along with Awagaha Swedana (Sit'z bath). Study suggests that use of straight posture support medical treatment of anorectal bleeding significantly and offer relief in associated symptoms. Study concluded that patient suffered with anorectal bleeding should use western system for defecation instead of Indian system to prevent complication of bleeding.

\section{References:}

1. Anantaram Sharma ; Sushrut Samhita Vol.2, $1^{\text {st }}$ edition ; Chaukhamba Sanskrit Sansthan Varanasi 2004, Chikitsa Sthana, Adhyaya no.24, Anagatabadhapratisheda, pg no359.

2. Ram Dayal Joshi, Ram Narayan Vaidya, Ayurveda Saar Sangraha, Sri Vaidya Nath Ayurved Bhavan Sanskaran, Shadhanmaran Prakaran, 2011; 556.

3. Sushruta. Sushruta Samhita with English translation of text and Dalhana'scommen-tary 
along with critical notes. Edited and translated by Priyavrat Sharma. Varanasi; Chaukambha Vishwabharati oriental publishers and distributors. Reprint 2005. 695.

4. http://patient.info/in/health/anal-fissure. Accessed on 25/06/2016 at $15.00 \mathrm{hrs}$.

5. Agnivesha, 'CharakaSamhita', revised by Charaka and Dridhbala with 'Ayurveda Dipika' commentary, by Chakrapanidatta, edited by Vaidya Jadavaji Trikamaji Acharya, Krishnadas Academy, Gopal Mandir Lane, Varanasi -221 001, (India), reprint 2000 Sutra Sthana 14/44.

6. Anantkumar shekokar and Dr Kanchan Borkar, Comparative Role Of Squating Posture And Straight Posture Of Defecation In Fissure In Ano Along With Awagaha Swedana (sitz bath), Europen Journal Of Biomedical And Pharmaceutical Science, Vol.3 No.12 Des 2016, ISSN
NO.23498870.

7. En.wikipedia.org/wiki/LIFT technique. Accessed on $19 / 10 / 2016$ at $13.00 \mathrm{hrs}$.

8. http;//dx.doi.org/10.3393/jksc.2012.28.1.7. Accessed on 13/12/2016 at $16.00 \mathrm{hrs}$.

9. Org/wp-content/uploads/2015/11/BookletToileting. Accessed on 14/01/2017 at $14.00 \mathrm{hrs}$.

10. http://www.medicalnewstoday.com/ articles/186514.php. Accessed on 25/02/2017 at $19.00 \mathrm{hrs}$.

11. http://my.clevelandclinic.org/health/ diseases_conditions/hic-understanding-rectalbleeding. Accessed on 05/03/207 at $17.00 \mathrm{hrs}$.

12. http://www.aafp.org/afp/2001/0615/p2391.html. Accessed on 11/03/2017 at $17.00 \mathrm{hrs}$ 